"Przegląd Prawa Konstytucyjnego"

------ ISSN 2082-1212 ------

DOI 10.15804/ppk.2014.04.08

Nr $4(20) / 2014$

\title{
Recenzja
}

\section{Eukasz Danel, Izba Lordów w parlamentaryzmie brytyjskim, Wydawnictwo Sejmowe, Warszawa 2014, ss. 376}

Izba Lordów jest jednym z najbardziej charakterystycznych symboli ustroju Zjednoczonego Królestwa Wielkiej Brytanii i Irlandii Północnej. Izba ta nie pochodzi z wyborów bezpośrednich i powszechnych, a prawo zasiadania w niej posiadają również parowie dziedziczni. Wprawdzie liczne reformy konstytucyjne zmienily w ciągu ostatniego stulecia zakres kompetencji oraz skład Izby Lordów, jednak nadal może ona uchodzić za przykład ewolucyjnego podejścia Brytyjczyków do refom instytucji politycznych oraz zakorzenienia systemu konstytucyjnego $\mathrm{w}$ tradycji i dorobku minionych wieków.

W polskiej literaturze przedmiotu nie było dotychczas monografii poświęconej brytyjskiej Izbie Lordów. Wskazać można oczywiście prace poświęcone różnym aspektom parlamentaryzmu brytyjskiego, ale zwykle w większym stopniu koncentrowały się one na posiadającej większe znaczenie ustrojowe Izbie Gmin'1 a w części treści w nich zawarte przestały być aktualne i posiadają jedynie walor historyczny ${ }^{2}$. Z tym większym zadowoleniem należy odnotować pojawienie się na rynku monografii autorstwa doktora Łukasza Danela Izba Lordów w parlamentaryzmie brytyjskim. Praca ukazała się nakładem Wydawnictwa Sejmowego w Warszawie w 2014 r. Choć nie znajdziemy w książce na ten temat wzmianki, należy domniemywać, że praca jest,

Zob.: P. Silk, R. Walters, Jak działa parlament brytyjski, Warszawa 1994; A. Zięba, Parlament Wielkiej Brytanii, Warszawa 1994; A.S. Bidwell, Blaski i cienie parlamentaryzmu brytyjskiego, Warszawa 2004.

2 Zob.: A. Meszorer, Brytyjski system parlamentarny w zarysie, Warszawa 1962. 
ulepszoną o uwagi recenzenckie, wersją rozprawy doktorskiej przedstawionej i obronionej przed Radą Naukową Instytutu Politologii Wydziału Nauk Społecznych Uniwersytetu Wrocławskiego w 2012 r. $^{3}$

Monografia rozpoczyna się wstępem, w którym przedstawiono krótką charakterystykę Izby Lordów oraz postawiono podstawowe pytania badawcze. Ambitnym celem, jaki sobie autor postawił, była „nie tylko analiza przeobrażeń strukturalnych i funkcjonalnych, ale także próba ukazania, jak mimo wielu niesprzyjających okoliczności zgromadzenie to potrafiło odnaleźć swoje miejsce i dostosować się do zmieniających się uwarunkowań politycznych" (s. 10).

Książka obok wstępu podzielona jest na cztery rozdziały oraz zakończenie. Dołączono do niej pięć aneksów dotyczących hierarchii tytułów parowskich, prezentacji i zaprzysiężenia nowych członków Izby, sali posiedzeń, otwarcia sesji oraz nadawania sankcji królewskiej projektom ustaw.

Rozdział pierwszy recenzowanej książki ma charakter historyczny. Koncentruje się na genezie Izby Lordów oraz jej ewolucji ustrojowej do końca XIX w. Autor w rozdziale tym sprawnie prowadzi nas przez zmienne losy Izby Lordów od średniowiecza, przez rządy dynastii Tudorów i Stuartów, do początków rządów parlamentarnych. Pewne uwagi krytyczne można postawić ostatniemu podrozdziałowi dotyczącemu wpływowi dziewiętnastowiecznych procesów demokratyzacyjnych na redefinicję pozycji ustrojowej Izby Lordów. Wydaje się, że autor zbyt mało miejsca poświęcił reformom prawa wyborczego i ich konsekwencjom dla całego ustroju brytyjskiego, z Izbą Lordów włącznie. Problematyka ta posiada bardzo bogatą literaturę przedmiotu, szczególnie angielskojęzyczną. Z polskich opracowań można wskazać choćby klasyczną pracę Władysława Konopczyńskiego ${ }^{4}$, a z nowszych - opracowanie Macieja Rakowskiego 5 .

Rozdział drugi poświęcony jest reformom i planom reform Izby Lordów w XX w. Autor przedstawia w nim genezę i przebieg kryzysu politycznego, którego efektem było uchwalenie ustawy The Parliament Act z 1911 r., która

3 http://www.nauka-polska.pl/dhtml/raportyWyszukiwanie/listaLudzieNauki.fs (10.10.2014).

4 W. Konopczyński, Dzieje parlamentaryzmu angielskiego, Warszawa 1922.

5 M. Rakowski, Wptyw dziewiętnastowiecznych reform wyborczych na rozwój brytyjskiego parlamentaryzmu, „Studia Wyborcze” 2010, t. X, s. 69-91. 
znacząco osłabiła pozycję Izby Lordów w brytyjskim systemie konstytucyjnym. W dalszej części rozdziału omówiono reformę z 1949 r., ograniczającą moc weta zawieszającego Izby, reformę wprowadzającą na mocy ustawy The Life Peerages Act z 1958 r. parostwa dożywotnie oraz reformę z 1963 r. stwarzającą możliwość prawną zrzeczenia się parostwa. Osobną część rozdziału poświęcono okresowi od 1964 r. do 1997 r., kiedy to pomimo licznych zapowiedzi reform Izby żadna nie doszła do skutku. Szukając odpowiedzi na pytanie, dlaczego nie doszło w tym okresie do jakiejkolwiek reformy Izby, autor słusznie zauważa, że szczególnie po reformie z 1958 r. Izba Lordów była już zupełnie inną instytucją, niż ta, z którą musiały walczyć poprzednie gabinety laburzystowskie (s. 126). Wyodrębniona część rozdziału poddaje analizie reformę z 1999 r. Na pochwałę zasługuje fakt, że autor korzysta przy swojej analizie z bogatej bazy dokumentów rządowych i parlamentarnych. Rozdział kończą rozważania dotyczące zaniechań w dokończeniu reformy Izby Lordów przez kolejne gabinety laburzystowskie (2001-2010) oraz omówienie rządowego projektu reformy Izby Lordów z 2011 r. wycofanego z prac parlamentarnych w 2012 r. Krytycznie należy podkreślić, że autor nie skorzystał w swojej analizie z dwóch bardzo ważnych prac Petera Doreya i Alexandry Kelso oraz Chrisa Ballingera dotyczących reform ustrojowych i pozycji konstytucyjnej Izby Lordów ${ }^{6}$. Wskazać można także szereg pominiętych w książce artykułów dotyczących omawianych problemów zamieszczonych w prestiżowych zagranicznych czasopismach naukowych ${ }^{7}$ oraz pozycji w polskiej literaturze przedmiotu ${ }^{8}$. Dyskusyjne jest także pominięcie w analizowanym rozdziale problematyki reformy z 2005 r., w efekcie której powołano oddzielny Sąd Najwyższy i odebrano Izbie Lordów kompetencje sądowe. Wprawdzie główny tok narracji dotyczy pozycji Izby w parlamentaryzmie brytyjskim,

6 P. Dorey, A. Kelso, House of Lords Reform Since 1911: Must the Lords Go?, Palgrave Macmillan 2011, ss. 243; Ch. Ballinger, The House of Lords 1911-2011. A Century of Non-Reform, „Hart Studies in Constitutional Law”, Vol. 1, Oxford 2012, ss. 249.

7 A. Kelso, Reforming the House of Lords: Navigating Representation, Democracy and Legitimacy at Westminster, „Parliamentary Affairs” 2006, No. 4; M. Russell, House of Lords reform: Are We Nearly There Yet?, „The Political Quarterly” 2009, No. 1.

8 M. Drzonek, Brytyjska Izba Lordów: skład, funkcje i niektóre reformy dokonane w XXw., „Zeszyty Naukowe. Acta Politica” 1998, nr 11; K. Urbaniak, Projekt bezpośrednich wyborów do brytyjskiej Izby Lordów, [w:] Prawo wyborcze i wybory. Doświadczenia dwudziestu lat procesów demokratyzacyjnych $w$ Polsce, red. A. Stelmach, Poznań 2010. 
jednak odebranie kompetencji sądowych rzutowało bardzo mocno na pozycję Izby w brytyjskim systemie konstytucyjnym9 .

Rozdział trzeci książki poświęcony jest członkostwu, organizacji wewnętrznej i zasadom działania Izby Lordów. W rozdziale tym w pierwszej kolejności poddano analizie członkostwo w Izbie, słusznie wskazując, że cały czas pomimo powołania Komisji ds. Nominacji oraz licznych prób nadania transparentności procesowi nominacyjnemu decyzje w sprawie powołania parów dożywotnich podejmuje jednoosobowo premier. W dalszej części rozdziału skoncentrowano się na organach wewnętrznych Izby Lordów. Autor umiejętnie wskazuje na różnice pomiędzy instytucją Lorda Kanclerza, do 2005 r. stojącego na czele Izby, a nowym organem - Lordem Spikerem, prowadzącym obecnie obrady Izby. Szkoda, że autor nie odwołał się przy tej analizie do ciekawych spostrzeżeń poczynionych w polskiej literaturze przedmiotu $^{10}$.

Osobna część rozdziału koncentruje się na komisjach Izby Lordów oraz organizacji ich pracy. Autor w sposób bardzo kompetentny przedstawia $\mathrm{w}$ niej najważniejsze komisje parlamentarne oraz dokonuje ich podziału ${ }^{11}$. Ważną część rozdziału stanowi wyodrębniona analiza politycznego układu sił w Izbie Lordów. Rozdział kończą rozważania dotyczące organizacji i przebiegu prac w trakcie sesji parlamentarnej. Ta część rozdziału napisana jest bardzo kompetentnie, $\mathrm{z}$ bardzo mocno zauważalną znajomością rzeczy. Autor w swojej analizie swobodnie posługuje się wiedzą dotyczącą zarówno rozwiązań proceduralnych, jak i, co warte podkreślenia, praktyki parlamentarnej.

Ostatni, czwarty rozdział książki zawiera analizę funkcji Izby Lordów i jej udziału w realizacji funkcji parlamentu brytyjskiego. Autor dokonuje prze-

9 Zob. np.: The Judicial House of Lords: 1876-2009, eds. L. Blom-Cooper, B. Dickson, G. Drewry, Oxford University Press, Oxford 2009; D. Woodhouse, United Kingdom The Constitutional Reform Act 2005 - defending judicial independence the English way, „International Journal of Constitutional Law” 2007, No. 5(1); P. Mikuli, Reformy sadownictwa w Zjednoczonym Królestwie w latach 2005-2009, [w:] Od Thatcher do Blaira. Wielka Brytania na przełomie XX i XXI w., red. B.H. Toszek, T. Czapiewski, Szczecin 2010.

10 E. Gawin-Bator, Speaker Izby Gmin a Speaker Izby Lordów, „Przegląd Sejmowy” 2008, nr 1.

11 Problematyka ta nieraz stwarzała dużo problemów w polskiej literaturze przedmiotu, zarówno jeśli chodzi o ich nazewnictwo, jak i funkcje. Zob.: A. Meszorer, op.cit. 
glądu funkcji Izby, wskazując, że w większości są to funkcje typowe dla drugich izb parlamentu. Godne podkreślenia są uwagi autora dotyczące pierwotnych kompetencji parlamentu, w połączeniu z zasadą jego suwerenności. Osobną część rozdziału stanowi analiza procesu legislacyjnego w Izbie Lordów. Autor z dużą kompetencją przedstawia poszczególne stadia tego procesu, wskazując na jego odrębności w stosunku do analogicznego procesu w Izbie Gmin. W rozdziale znajdziemy także rozważania dotyczące relacji i współzależności w procesie legislacyjnym między Izbą Lordów a Izbą Gmin. Na podkreślenie zasługuje fakt, że autor sprawnie posługuje się przy swojej analizie zarówno znajomością prawa parlamentarnego, jak i praktyki. Należy także zgodzić się z postawioną tezą dotyczącą realnego znaczenia Izby Lordów w realizacji funkcji ustawodawczej parlamentu, że „mimo (...) wszystkich mniej lub bardziej historycznych ograniczeń czy to o charakterze zwyczajowym, czy ustawowym, uprawnienia Izby Lordów i jej rola w realizacji funkcji ustawodawczej parlamentu są w praktyce znaczne" (s. 308).

Rozdział kończy analiza instrumentów funkcji kontrolnej Izby (oświadczenia, pytania, debaty) oraz rozważania dotyczące specyfiki prowadzenia obrad w Izbie, ich przebiegu oraz podejmowania decyzji. Pewnym mankamentem tego rozdziału jest brak szerszego odniesienia do problemu legitymacji politycznej i prawnej Izby Lordów oraz pominięcie najważniejszej chyba obecnie pozycji książkowej dotyczącej analizy pozycji ustrojowej i znaczenia Izby Lordów we współczesnym ustroju brytyjskim autorstwa Meg Russell ${ }^{12}$.

Książkę zamyka zakończenie nawiązujące do wszystkich najważniejszych podnoszonych w pracy zagadnień. Pewnym brakiem, z punktu widzenia upowszechniania wiedzy i poszerzania debaty naukowej, jest brak w książce streszczenia i spisu treści w językach obcych (w szczególności w języku angielskim).

W podsumowaniu należy podnieść, że książka Łukasza Danela, pomimo wskazanych mankamentów, głównie natury warsztatowej, jest ważną i ciekawą pozycją dotyczącą systemu ustrojowego współczesnej Wielkiej Brytanii. Na szczególne podkreślenie zasługuje jej aktualność. Rozważane problemy są przedmiotem sporów w bieżącej debacie politycznej. Ważną zaletą książ-

12 M. Russell, The Contemporary House of Lords. Westminster Bicameralism Revived, Oxford 2013 . 
ki jest także duża baza faktograficzna dotycząca prawa i zwyczajów parlamentarnych. Książka niewątpliwie wypełnia także lukę w polskiej literaturze przedmiotu. Z całą pewnością pozycję tę można polecić wszystkim, którzy zainteresowani są przemianami konstytucyjnoprawnymi i politycznymi w Zjednoczonym Królestwie Wielkiej Brytanii i Irlandii Północnej oraz prawem i zwyczajami parlamentarnymi.

Krzysztof Urbaniak Uniwersytet Adama Mickiewicza w Poznaniu 